\title{
The Figure of Kumbakarna in Wayang Performance: A True Knight Model in Serat Tripama by Mangkunegara IV
}

\author{
Herliyana Rosalinda ${ }^{1}$ Sarwanto $^{2} \quad$ Dharsono $^{2} \quad$ Budi Setiyono $^{3}$ \\ 1. Doctoral Art Studie Program, Institut Seni Indonesia (ISI) Surakarta, Indonesia \\ 2. Professor, Institut Seni Indonesia (ISI) Surakarta, Indonesia \\ 3. Faculty of Performance Arts,Department of Ethnomusicology, Institut Seni Indonesia (ISI) Surakarta, \\ Indonesia
}

\begin{abstract}
This article focuses on the study of the figure of Kumbakarna who became a role model for the Javanese. Kumbakarna was seen as a true knight who never broke his promise in defending the country until the end. This characteristic was implied in Serat Tripama, a traditional parchment authored by Mangkunegara IV which depicts three role models, namely Bambang Sumantri, Karna, and Kumbakarna. This article aims to describe and analyze the figure of Kumbakarna as a true knight which reflects the thoughts and values held by Mangkunegara IV. This articleused a library research with a hermeneutic approach as a tool to interpret Mangkunegara's thoughts contained within Serat Tripama. The results and discussion of this article explains that the government under Mangkunegara IV is very concerned about their administrative duties, especially in teaching by giving examples of trueknight figures who can become role models for the people and the military in Indonesia. That there is no need to have a beautiful physique to become a true knight figure aside of a strong determination to love the homeland. This is depicted bythe figure of Kumbakarna who was willing to sacrifice his life to defend his country, Alengka Kingdom.
\end{abstract}

Keywords: Kumbakarna, Mangkunegara IV, Serat Tripama, True Knight, Wayang

DOI: $10.7176 / \mathrm{ADS} / 86-02$

Publication date:October $31^{\text {st }} 2020$

\section{Introduction}

The arts of Wayang performance are still preserved and continued to receive the attention of the Indonesian people for centuries. This is because there are two main things that support the arts of Wayang performance, namely staying responsive to the changing times and being consistent with the messages of moral values. Wayang performances as a product of Javanese culture are well known not only by the Javanese people and the Indonesian people in general, but also by foreigners and people coming from outside of Indonesia. According to Sarwanto, of all the various kinds of Wayang performances, Wayang Purwa has a special place in the hearts of the Javanese because it has close ties with the Javanese people.(Sarwanto, 2007).

The arts of Wayang performance, specifically Wayang Purwa,are dedicated to the people with a vision ofmemayu hayuning bawanaandmemayu hayuning sasama ${ }^{l}$. This vision made the puppeteers of the past to never think about rewards in performing the arts of Wayang. This isbecause for the puppeteers, the goal behind the Wayang performances was to have the opportunity to disseminate moral messages to society, especially the Javanese. The puppeteers accommodate social symptoms with careful use of idioms for Wayang Purwa performances in attractive packaging. Hence, the puppeteers were able to present a Wayang Purwa performance known as pakeliran adiluhung. Therefore, the puppeteers in the past had charisma and occupied a central position in people's lives (Mutiyoso inDhanang, 2010).

Wayang stories that are presented at Wayang Purwa performances with various plays became educational entertainment activities for the people. This was done in order to teach moral values to the society.In order for the community to behave well, to know cultural teachings, and to comply with norms,an example is needed that can be absorbed subtly through plays and entertainment. This is the purpose behind the arts of Wayang performances. Along with the times, when Wayangperformances have become embedded in the hearts of the people, not only the puppeteers who play a role in spreading the cultural teachings contained in Wayang, but also community leaders through their implementation of moral values contained in Wayang performanceswhich are applied to their policies to convey their leadership characteristics. One of these leaders was Mangkunegara IV. In order to achieve his goals through his leadership, Mangkunegara IV was actively contributing in Javanese literary arts, for example in the form of literary works such as serat or traditional parchments that are able to describe his thoughtsand values in an effective way. Through these parchments, the thoughts and regulations

${ }^{1}$ memayu hayuning bawana means to be kind to living things all over the world while memayu hayuning sasama means to be kind to fellow human beings. The concept of Mamayu hayuning bawana (to create prosperity on earth) is a reflection of the Javanese society's behavior in harmonizing an order based on the macrocosm and microcosm concepts, which is the harmonization of jagad gumelar (macrocosm) and jagad gumulung (microcosm) (Anderson, 2001). 
made by Mangkunegara IV can be conveyed well to the public.

During his reign, Mangkunegara IV ordered the writing of approximately 42 books, including Serat Wedhatama, Serat Tripama and Gamelan compositions. Among his works, this article attempts to describe one of the works done by Mangkunegara IV, namely Serat Tripama. This article focuses the discussion on one figure depicted within, namely Kumbakarna. The figure of Kumbakarna, although depicted in the form of a giant which stands beside Rahwana, is noble-hearted, wise, and honest. This is reflected in his attitude that condemns Rahwana's actions when he kidnaps Rama's wife, Sinta. Kumbakarna asked Sinta to be returned to Rama. Also, when Alengka Kingdom was attacked by Rama, Kumbakarna was ordered to become a general in the war against Rama since many of Rahwana's colonel died in the war, but he refused this order. However, because AlengkaKingdom almost fell, Kumbakarna went to war not to defend Rahwana but to defend his homeland. At the end, Kumbakarna died in the hand of Sri Rama and hewas considered as a hero (interviewwith Soetarno, June 23, 2020).

This article focuses on Kumbakarna as the object of discussion because there are many unique characteristics that deserve to be mentioned, especially as a role model for the people not only during the leadership of Mangkunegara IV but more so in recent years. The characters and life stories behind the figure of Kumbakarna contained in the epic Ramayana are considered as noble so that people could be able to find real examples of rolemodels in braving their lives. Nowadays, issues concerning body shaming, globalization, and national security are sensitive issues that permeates in the society. Through studying the figure of Kumbakarna, it can be interpreted that a perfect physique and origin are not the defining factor to become a role model. This is in line with Dharsono who said that, in facing the global, we must be able to knit the past to build a futureby exploring, studying, and cultivating the potential for plurality of local cultures as capitalsso that we would be able to compete in the global arena. This means that to face global issues, we must study locally; the more global the more local. Traditions in a society can change, but cultural values are considered adiluhung(honorable) and should be still preserved(Kartika \& Perwira, 2016, pp. 175-176).

\section{Research Method}

This research is a library research using the Anthropology perspective. The literature research was done in order to find information about facts or data with the main source in the form of books, literature, notes, and reports that are related to the figure of Kumbakarna in Serat Tripama by Mangkunegara IV. For the findings and discussion, this research is reconstructed in a descriptive qualitative manner which aims to reveal real phenomena and objective problems in society. Fieldwork was also done to support sociological perspectives with a methodological extension of ethnomethodology. Ethnomethodology provides an explanation of how people understand their daily activities so that they can behave in a socially acceptable way (Singleton Jr, Royce, Bruce C. Straits, 1988, 308)

This research uses the hermeneutical approach. Ahimsa emphasized that in art, hermeneutics means explaining and expressing the meaning of the artistic texts. What is being revealed is not a causal relationship, but an understanding behind the artistic text. An important step in hermeneutics is interpretation, which means revealing what is considered as a figure meant by an artistic text,which is then seen as the meaning behindthe analysis done to the artistic text (2000: 403-404). Hermeneutics was used as a tool to interpret Mangkunegara IV's work and thoughts in Serat Tripama to find the concept of the true knight character in the figure of Kumbakarna. There are also sources that are used consisting of primary sources and secondary sources. The primary source is in the form of traditional Javanese parchments archive, namely serat, with a case study on Serat Tripama. Secondary sources are articles and books which are in line with the object of this research.

\section{Research Results and Analysis}

3.1. The story of Kumbakarna as a knight from the Epic of Ramayana

Kumbakarna is the second child of Begawan Wisrawa. His mother was named Dewi Sukesi. He has an older brother named Rahwana or Dasamuka and younger siblings named Dewi Sarpakenaka and Gunawan Wibisana.The marriage between Begawan Wisrawa and Dewi Sukesi happened because they could not control their lust. As a result, the four children they gave birth to also had the traits of excessive appetence.Dasamuka could not control hiswrathful rage and greed, Kumbakarna indulges in gluttony and sloth. Dewi Sarpakenaka always indulges in her lust, while Gunawan Wibisana always satisfies the desire to find the true truth.Among his brothers, only Wibisana was born handsome. The other siblings, like Kumbakarna, are born as giants. The name Kumbakarnaconsists of two-wordfragments; "Kumba" and "Karna". "Kumba" means jug and "Karna" means ear. So, Kumbakarna can be interpreted as the one who has big ears like a jug. This is true to Kumbakarna's traits as he has very good hearing befitting to the name he has. The figure of Kumbakarna as a giant in Wayang Kulit can be seen in figure 1 below. 


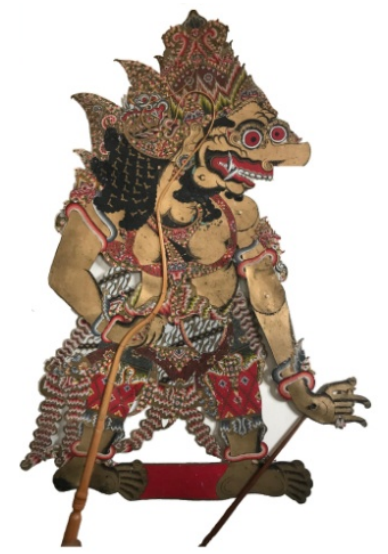

Figure 2. Kumbakarna as depicted in Wayang Kulit

Towards adulthood, these four siblings went to a retreat to Mount Gohmuka with different purposes. Like the other siblings, Kumbakarna entered a state of meditation for many years. Finally, the wise god Batara Narada came to meet him. To the wise god, Kumbakarna first began to express his wish to live a thousand years so that he could enjoy food in this world for a long time. Batara Narada was willing to fulfill the request, but warned that the longer a person lives, the more opportunities he has to sin. After all, people who live long doesn't mean they don't get older. The older a person is, the weaker the body will be and the less the ability of the tongue to enjoy the taste of food.

Hearing Batara Narada's advice, Kumbakarna realized his mistake and changed his request. He wanted to be able to sleep as long as he could and only wake up when he intended to wake up. He intents that if he sleeps, it will not bring trouble to other people, so that it will reduce the opportunity for him to sin. He only woke up when he wanted to eat. The gods granted the request. Besides this request, Kumbakarna also received two powers, namely Aji Gedhongmengo, which makes him able to eat extraordinary amounts of food and Aji Gelapsaketi, which causes him to yell loudly so that he emits a strong sound wave that can make his opponent bounced away.

Kumbakarna was once assigned by his brother to propose to Dewi Kekayi and Dewi Sumitrawati to become the brides for Dasamuka. The two beautiful women were daughters of King Sumaresi from the Suwelareja Kingdom. At that time, King Sumaresi put forward a condition, the application would be accepted if Kumbakarna could defeat Resi Kala, King Sumaresi's brother who became a powerful hermit. After fighting for days, Kumbakarna was unable to beat his opponent. Because of this, Dasamuka failed to marry the two daughters of the Suwelareja Kingdom. This leads to Dasamuka's action in kidnapping Dewi Sinta, a beautiful princess that is the bride of Ramawijaya. When Dasamuka kidnapped Dewi Sinta, Kumbakarna and Wibisana tried to make his brother realize that the act was wrong. They suggested that Dasamuka immediately release Dewi Sinta and return the princess to her husband, Ramawijaya. Hearing this suggestion, Dasamuka was angry and throw curses to Kumbakarna and Gunawan Wibisana. Because he could not stand his brother's cursing, Kumbakarna immediately returned to his house at Kasatrian Pangleburgangsa and went to sleep. He did not wake up until war broke out between the Alengka Kingdom troops and the monkey soldiers who were helping Ramawijaya.

When Alengka Kingdom loses a number of soldiers and generals, Dasamuka ordered his son, Indrajit to wake Kumbakarna up. It turned out that it was not easy to wake Kumbakarna. It was only after Indrajit plucked the hair growing on hiswulucumbu(big toe) that Kumbakarna awoke. Indrajit said that Kumbakarna was asked to meet Dasamuka. Arriving at the Alengka palace. Kumbakarna was served by Dasamuka with a thousand tumpeng rice and eight ingkung (piles) of elephant meat. After finishing eating the food, Dasamuka apparently asked Kumbakarna to go to the battlefield to face the attack of the monkey soldiers. Kumbakarna immediately refused, because in his opinion, the war occurred only because of the outrageous nature of Dasamuka who kidnapped someone else's wife. Dasamuka then cursed his younger brother even more, calling him as a man who just living as a glutton who doesn't know himself, never works, and doesn't care about the fate of the nation and the country. Hearing the painful blasphemy, with his supernatural powers, Kumbakarna vomited up everything he had eaten, whole and fresh. After that he resolved himself to go the battlefield, but not because of the reason to defend the anger and the blasphemous act of Dasamuka. Kumbakarna said to Dasamuka, "I went to fight for my homeland, Alengka. I fought the enemy who came to invade my blood, Alengka. This is not to defend your wrathful nature."

Kumbakarna fought earnestly wearing all white clothes. His fighting causedmany casualties on the part of the monkey soldiers. With Aji Gelapsaketi at his disposal, hundreds of monkey soldiers were blown away, some of them died because of it. Because Kumbakarna is difficult to match, Ramawijaya and Laksamana are forced to 
go to the battlefield to personally engage themselves with Kumbakarna. They both showered the giant with arrows. At first, Kumbakarna's hands were cut off by the relic arrows of Ramawijaya and Laksamana. Regardless of the pain that Kumbakarna was suffering, he continued to fight and caused many victims in the monkey soldiers side. Ramawijaya and Laksamana continued their arrow attacks until Kumbakarna's legs were stumped. However, this giant didn't give up. By rolling his body, now without hands and feet, he still managed to kill many monkey soldiers. Rama and Laksamana were forced to point their arrows at Kumbakarna's neck. Kumbakarna then fell as a hero defending his homeland. The condition of Kumbakarna's death was due to the curse of Jambumangli on his father, Begawan Wisrawa. Jambumangli who was killed by Begawan Wisrawa lostboth of his hands and feet before being killed.

Kumbakarna's wife is a beautiful nymph named Dewi Asnawi. It was Dasamuka who gave thisbeautiful nymph to Kumbakarna to be his wife. Dewi Asnawi was actually a gift from Dasamuka when Dasamuka invaded Kahyangan(the heaven) to ask for a hand in Dewi Sri Widawati.The gods were overwhelmed by his request. Through negotiations with Batara Endra, finally Dasamuka which is the king of Alengka,was gifted with three nymphs as a substitute for Dewi Widawati. The three nymphs were Dewi Tari who was married to Dasamuka, Dewi Asnawi who was later wed to Kumbakarna, and Dewi Triwari who was given to Gunawan Wibisana.

From this marriage, Kumbakarna had two sons, namely Asnawi Kumba and Kumba-Kumba. Like their father, these two children also died when they faced the monkey soldiers of Ramawijaya. When Kumbakarna decided to go into a sleep retreat after disagreeing with Dasamuka, he called five of his giantunderlings to educate and care for Asnawi Kumba and Kumba-Kumba. The five giant underlings are Kala Kampana, Akampana, Prajangga, Wilohitaksa, and Dwajaksa. They each have different powers. The five giants did their job well until the end. Like Kumbakarna and his two children, they all died in this war when Ramawijaya and the monkey soldiers invaded Alengka to free Dewi Sinta.

In the Makutharama play, it is told that the spirit of Kumbakarna would later come to Gunawan Wibisana, who had become a hermit. To his younger brother, the spirit of Kumbakarna complained that he could not find the path to reach perfection. Wibisana suggested that his brother's spirit merge with Bima, occupying his right thigh. In this way the Kumbakarna spirit will eventually be able to reach perfection(Wangi, 1999, p. 365).

Though Kumbakarna shines as a knightly figure, the story puts him on the wrong side, serving Dasamuka as an antagonist. Usually the knightly figure is always portrayed standing in the right side as the protagonist, but the presence of the Kumbakarna character on Dasamuka / Rahwana side makes the storyline balanced. This told that even in the dark side, there exists a light. Darmoko said that, the image of Kumbakarna, as it is widely spread in society as a knight, has the character with a spirit of "right or wrong it is still my country" (Benar atau salah adalah negaraku)(interview, June 23, 2020).He is aware that he is standing on the wrong side, but he still holds his determination to continue to defend his country which has provided life to him and all the people in it whom he loves.

\subsection{Knightly Figure in Wayang Performances}

The ideal concept of a Javanese man represented in Wayang is called satriya pinandita, which the ideal life of a knight or leader who has a satriya characteristics. Satriya as the ideal human being, is a knight in Wayang stories who is always shown as a brave character, defender of truth, and has perfect morality. Since he is perfect in his actions, deeds, and thoughts, the figure of a satriya or knight must be imitated by everyone and the commoners which was called kawula alit. The knights in Wayang play which was taken from the Epic of Ramayana are represented by the figures of Rama, Laksamana, and Wibisana. As for the wayang play which takes the story from the Mahabharata, the knights are represented by the figures ofthe Pandavas (Yudistira, Bima, Arjuna, Nakula, Sadewa, and their children)(Widijanto, Waluyo, \& Suyitno, 2020).

In Wayang Kulit, the concept of Javanese leadership is always identified with a king who has knightly values. The king who has knightly values is always referred to as the personification of God (Wahyu Tuhan).Therefore, he is absolute. The knightly king in Wayang story is told by the puppeteer as "ratu satriya gung binathara bau denda anyakrawati, wenang wisesa ing sanagari, ber budi bawa leksana, ambeg adil paramarta" (the king who has the power of the gods, keeper of the law and ruler of the world, the highest power of all nation, full of noble character and fair to one another). A knight character is depicted as a perfect and ideal figure to be a role model and to protect society. The visualization of these knight characters inWayang Kulit, specifically in Wayang Purwa, usually embodies physical traits that confirm that the Wayang figure is indeed a knight. Such example of these physical traits can be in the form ofgallant body posture. The wayang characters with gallant bodiy postures, which usually represented the figure of kings, are grouped together as Wayang Gagahan. Wayang Gagahan is larger in size than the Wayang Putren, which is the female characters in Wayang stories, and Wayang Bambang, which is the male characters in wayang stories. The special characteristic of this 
Wayang Gagahan is the existence of the crownwith three jamang ${ }^{l}$. This special characteristic can be seen in figure 1 .

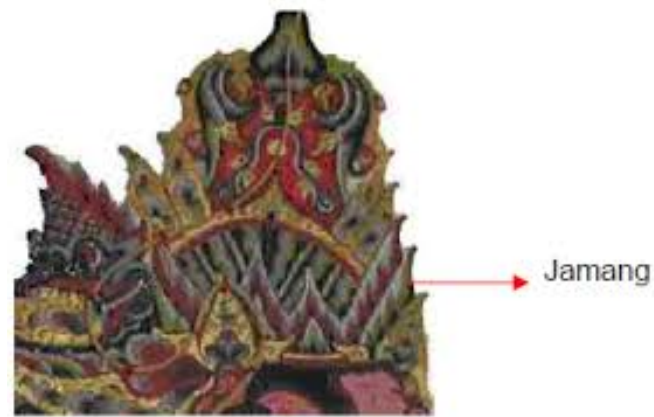

Figure 2. The example of jamang in Wayang Purwa

\subsection{The Ethical Thought of Mangkunegara IV on Soldier based on Serat Tripama}

The loyalty of a soldier is shown by his devotion, dedication, and his sacrifice to the country. The concept of loyalty to the state and homeland is contained inSerat Tripama written by Mangkunegara IV. Serat Tripama is one of Kanjeng Gusti Pangeran Adipati Arya Mangkunegara IV's short works. It contains only 7 pada (stanza) Dhandhanggulaverse. Serat Tripama is thought to have been written in the 1860s and is a Javanese literary work containing a collection of macapat songs.It also consists of a collection of macapat songs from various metrum or rhythm (Setyawan \& Saddhono, 2018). The content of Serat Tripama displays exemplary attitudes of a knight in the real sense, which refers to a soldier or a state'smilitary service (Dhanang Respati, 2004).The contents of Serat Tripama are often chanted by school children and quoted as lyrics in gamelan music. Serat Tripama contains an example for soldiers to have knightlytraits, which are to be persistent and not afraid to defend the country. The word tripama itself comes from a combination of the word trior three and umpamaor example, referring to three figures in the world of Wayang, namely Patih Suwanda from Maespati, Kumbakarna from Alengka Kingdom, and Adipati Basukarna from Awangga. The three of them are considered mythical heroesin Javanese culture and can be looked upon as role models. They are described as having high loyalty and dedication to their country, prioritizing the interests of the nation and state above personal and family interests. The attitudes of the three figures also illustrate the various values that exist in Javanese ethics so that they could becomean example in living the life in society, nation, and state.

Kumbakarna is mentioned inSerat Tripamawithin theDhandanggula verse in the third and fourth stanza (pada), which reads:

"wonten maloh tuladan prayogi satriya gung nagri ing Ngalengka, sang Kumbakarna arane, tur iku warna diyu suprandane nggayuh utami duk wiwit prang ngalengka, dennya darbe atur mring rakaamrih raharja Dasamuka tan keguh ing atur yekti dene mengsah wanara. Kumbakarnakinenmangsahjurit; mring kang raka siratanlenggana nglungguhi kasatriyane ing tekad datan purun amung ciptalabuh nagari lannoleh yayah rena nyang leluhuripun wus mukti aneng ngalengka mangke arsa rinusak ing bala kapi punagimatingrana".

This can be translated to, "There are more exemplary characters of a good leader, the great knight of the Alengka Kingdom, Kumbakarna.Although his form is that of a giant, but he has the main character of a knight with a nationalist spirit" (Suprapto, 2017).The exemplary characters of Kumbakarna in Serat Tripama is about his nationalist spirit as a knight who defended his homeland until the end of his life, which is the kingdom of Alengka. Kumbakarna's persistence is also interpreted asthenatural truth which refers to the meaning of cultural truth. Cultural truth means the attitude of truth that refers to the culture it belongs to, including the meaning of the seven elements of culture, namely: the place or origin of the person he was born in, language, social systems, technology, knowledge, religion, and art (Rosalinda, 2019).

Even though the three Wayangfigures differ in status, role, and social environment as well as their position in their respective countries, all three share the same value of defending their homeland with a sense of responsibility. Through these three figures, Mangkunegara IV was intended to present the depiction of a true knight figure contained in the combination of the characters within these figures. Kumbakarna is a figure of a knight or warrior who is willing to sacrifice himself for the sustainability and integrity of his nation and country. However, he has an inverse comparison with another figure which is Bambang Sumatri who is devoted and very loyal to his king. Kumbakarna always opposed Dasamuka's policies which were often arbitrary and put the kingdom's loyal retainer in difficult position, so he decided to meditate in a long sleep in order to avoid the bad influence of his brother. Karna Basusena, another knightly figure, is depicted as a figure who is loyal to his promise, who is willing to sacrifice for someone who has helped him in attaining position. Just like Karna

${ }^{1}$ Jamang is a form of decoration on the head that is worn in the forehead 
Basusena, Kumbakarna also holds true to his promises, not to a person, but to his homeland, the kingdom of Alengka.

The figure of knights in Wayang that has been discussed in the above section implies that having a knightlycharacteristicmeans the figure has a perfect character. The meaning of this perfection includes both physical, action, personality, and self-defense. However, the thoughts of Mangkunegara IV in Serat Tripama proved that at that time, he had deconstructed the concept of knights in Wayang stories. Mangkunegara IV realizes that the three figures in Serat Tripama have their own weaknesses which, according to the general view of the Javanese people, should be avoided as the knight embodies perfection.However, as it is known, that good and bad qualities are something inherent in everyone that cannot be separated from human existence in his life. Moreover, the weaknesses of the three figures have been redeemed by their merits and devotion. The three of them deserved to be role models as an embodiment of a knightly traits. Mangkunegara IV emphasized the need for such qualities which must be possessed by true knights. However, he also realized that humans have limitations. Therefore, he tolerated soldiers to imitate only what was worthy of being emulated from these figures (Dhanang Respati, 2004).

\subsection{The Essence of a True Knight in the Figure of Kumbakarna}

The figure of Kumbakarna is taken from the Epic of Ramayana Wayang story which tells about the journey of Prabu Ramawijaya and Dewi Sinta. Raden Kumbakarna is the son of Resi Wisrawa and Dewi Sukesi. Kumbakarna is Dasamuka's brother, the king of Alengka. Other brothers who are also sons of Wisrawa and Sukesi are Sarpakenaka and Gunawan Wibisana. Kumbakarna likes to sleep and eat.Although he is a giant, he has the soul of a knight. This was shown within the story as he always opposes the attitudes and decisions of his brother, Dasamuka (which was also known as Rahwana). He prefers to meditate and avoid any quarrelsrelated to his life in Alengka kingdom.

Mangkunegara IV chose the figure of Kumbakarna to be an example in Serat Tripama because he was considered to have a nationalist spirit and deep love for his country. The depiction of Kumbakarna as an example of the spirit of nationalism may come as a strange choise for some people. This is because the figure of Kumbakarna is mostly known as a giant. in the Epic of Ramayana version of Wayang story, Kumbakarna is depicted as a symbol of theAluwamah. Aluwamahis the appetence that tends to be uncertain and unbalanced. The appetence of Aluwamah in human nature is very unstable, repeatedly changing sides between strong and weak. It can also be seen from the figure of Kumbakarna.He is a warrior of Alengka kingdom who must obey the king's orders, however, he does not want to obey his kings orders who always spread anger and wrath around.

With his thoughts in Serat Tripama, Mangkunegara IV tried to break the bad perceptions about Kumbakarna. Mangkunegara IV sees the good side of Kumbakarna which is his patriotic side towards his nation. In that context, Mangkunegara IV deconstructed the Javanese literature to describe the figure of Kumbakarna figure through Serat Tripama (Setyawan \& Saddhono, 2018).

Kumbakarna who was born as a giant was seen by the public as a scary figure. The giants in the Wayang stories are generally antagonists who have bad qualities in line with their grotesque appearance. However, the figure of Kumbakarna is the opposite.Even though he is portrayed as a giant, he has a noble heart. This is a proof that exemplary figures do not always come in beautiful physical appearances like the figures of the knightly Pandawa. Modern knights, which is equal to soldiers or national military services, can take inspiration from the thoughts of Mangkunegara IV through the figure of Kumbakarna.This is so that there is no need to be discouraged if we have a not so good-looking facial feature or have a body posture that is not considered ideal in the society. The resolve to defend the country is the main point that must be owned by every soldiers.

Kumbakarna's actions as described by Mangkunegara IV in Serat Tripama should be emulated as a form of the spirit to defend the nation. Even though he is in the form of a giant, Kumbakarna still has good qualities, namely devotion to the country and homeland. He is very aware that since his birth, the whole family has lived, stayed, grown, and prospered in Alengka Kingdom. This is what made him move out and joined the war because he does not want to see the Kiskendha Goa troops destroy his homeland. In the battle between Alengka and Prabu Ramawiyaja, Kumbakarna did not die in vain.He died on the battlefield as a hero who defended his homeland. Regarding the good side of Kumbakarna, the values of virtue that Kumbakarna represented are as follows: (1) First, being honest and fair, not agreeing with dangerous rage or violating the rights of others; (2) Second, upholding the sovereignty state and do not want or allow the homeland to be controlled by those who do not respect his homeland and only want to destroy it, and; (3) Third, loving the motherland along with the sincerity to sacrifice himself for the sake of his country even if his own live is at stake (Purwosaputro \& Sutono, 2015, pp. 572-573).

Kumbakarna is interpreted as an exemplary figure, because he has never broken his promise to always defend his country until the end of his life. Thus, there is a slogan that emerged in the Republic of Indonesia which says "NKRI Harga Mati" (Non-negotiable Sovereignty of the Unitary State of the Republic of Indonesia) which was deemed suitable as a description of the determination represented by the figure of Kumbakarna. 
"NKRI Harga Mati" is a slogan that is often echoed to declare ourselves that we agree and love the unity of the Republic of Indonesia as a whole with its four pillars, namely Pancasila, UUD 1945, NKRI, and Bhinneka Tunggal Ika (unity in diversity). When viewed from linguistics, "NKRI Harga Mati" is a form of term.In KBBI (Kamus Besar Bahasa Indonesia or the Indonesia Dictionary),term means a combination of words that accurately express the meaning of a concept, process, situation, or characteristic that is unique in a particular field. If in this case, "NKRI Harga Mati" is pronounced as a form, then its position is as a word that expresses the meaning of a situation, where it works as a phrase which states the condition of individuals who love and approve of NKRI. "NKRI Harga Mati" is also a language style or figure of speech that states something excessively, or what is commonly called a hyperbole figure. The location of the excessive sentence is in the combination of the words "Harga Mati" which roughly translates into "fixed price" which refers to embody the spirit of NKRI until the end of life.

Morphologically, the words "Harga Mati" is a compound word or word composition that is either free or bound. Hence, a construction is formed that has a different lexical identity or can be called a new one from the original words when separated. The composition of "Harga Mati" is idiomatic,which refers to a construction whose meaning is not the same as the combination of its elemental meanings. Thus, the construction can be called as multiple interpretations. The meaning of "Harga Mati" itself is something that is final or inviolable.In other words, it is fixed without any negotiation. "Mati" (dying) is something that is certain and cannot be changed when the time comes. Thus, the slogan of "NKRI Harga Mati" is an affirmation that we agree that upholding the unity of the Republic of Indonesia as a whole is final that we must keepto protect the nation's independence and sovereignty (Abdullah, 2001).

The figure of Kumbakarna in the Wayang story was depicted as as a knight who obeys and listens to orders from his superiors if it is for the greater good of his nation. He also did not forget to repay the kindness he had received from his brother who introduced him to his beautiful wife, and also gave him a life in the form of clothing, food, and adequate housin. He felt grateful towards his brother even though his brother had ambitions and traits that were contrary to his values(interview with Bambang Sunarto, November 18, 2019). Kumbakarna never break his promise to always defend his country whatever the cause and the consequences.He accepted the risk in order to defend the country. That statement is part of a person's service to his country as a form of devotion to the divine gift that has been given towards his life (Soemitro \& Amzy, 2014, p. 201). Based on all of these traits exhibited by Kumbakarna in Serat Tripama, the meaning of true knights can be attached and appropriated to be carried by the figure of Kumbakarna.

\section{Conclusion}

Kumbakarna is the figure who was portrayed as a giant but exhibits the traits of a true knight. The meaning of a true knight is about a figure who should be an example for the people in society. Kumbakarna achieved this because in his life, he always adheres to his moral principles and never breaks his promise to always defend his homeland. Because of this attitude, Kumbakarna must be willing to continue to fight with his older brother (Rahwana) who is the king of the Alengka kingdom which stands in the antagonistic side within the story. However, Kumbakarna was willing to oppose the King's policies which were considered wrong in order to maintain the continuity of his country.

Mangkunegara IV contributed a lot of his thoughts in the field of literature, one of which was Serat Tripama. This literary work created by Mangkunegara IV basically provides a moral message related to his leadership reflection which prioritizes the role of warrior in life. One of the symbols of the ideal warrior is exemplified through the figure of Kumbakarna, whose life story in the Epic of Ramayana is always portrayed as a figure determined to defend the country. Through the figure of Kumbakarna, an understanding is obtained that to become a true knight (in the real sense, a reflection of the ideal soldier or military service figure), it is not seen from the ideal physique (good looking), but from a strong character who embodies a firm determination to always defend the country or the homeland.

\section{References}

Ahimsa-Putra, Hedy Shri Ed. (2000), Ketika Orang Jawa Nyeni, Yogyakarta: Galang Press.

Abdullah, T. (2001). Nasionalisme dan Sejarah. Satya Historika.

Anderson, B. R. (2001). Mitologi dan Tolerensi Orang Jawa. terj. Ruslani. Yogyakarta: Qalam.

Dhanang, R. P. (2010). DARI PAKELIRAN ADILUHUNG KE PAKELIRAN GLAMOR-SPEKTAKULER: Pertunjukan Wayang Kulit Purwa Gaya Surakarta dalam Perubahan Budaya. OMBAK.

Kartika, D. S., \& Perwira, N. G. (2016). Kreasi Artistik, Perjumpaan Tradisi Modern dalam Paradigma Kekaryaan Seni. Surakarta: LKBN Citra Sains.

Purwosaputro, S., \& Sutono. (2015). Identifikasi Nilai-nilai Keutamaan dalam Serat Tripama sebagai Bentuk Pengembangan Pendidikan Karakter Berbasis Budaya, SEMINAR HASIL-HASIL PENELITIAN 2014.

Sarwanto, S. (2007). Sekilas Tentang Perkembangan Pertunjukan wayang kulit di jawa dari masa ke masa 
Sebuah tinjauan historis. Lakon Jurnal Pengkajian \& Penciptaan Wayang, 4(1).

Setyawan, B. W., \& Saddhono, K. (2018). Nationalism Spirit of Kumbakarna Figure in Serat Tripama: an Deconstruction Literature Analysis. In Proceeding of the International Conference Tri Matra.

Singleton Jr, Royce, Bruce C. Straits, dan M. M. S. (1988). Approaches to Social Research. Oxford: Oxford University Press.

Soemitro, H., \& Amzy, N. (2014). Gugurnya Kumbakarna: Dharma dan Cinta. Respons, 19(2), 197-221.

Wangi, S. (1999). Ensiklopedi Wayang Indonesia, jilid 3. Jakarta: Sena Wangi.

Widijanto, T., Waluyo, H. J., \& Suyitno, S. A. (2020). Myth Deconstruction of Wayang Ramayana and Baratayuda in the Novel of Kitab Omong Kosong by Seno Gumira Ajidarma and Perang by Putu Wijaya.

\section{Resources:}

Name

Occupation

Field of study

Prof. Soetarno, DEA.

Lecturer and Professor, Institut Seni Indonesia, Yogyakarta

Wayang Studies

$\begin{array}{lll}\text { Name } & : & \text { Dr. Darmoko, S.S., M. Hum } \\ \text { Occupation } & : & \text { Lecturer, Universitas Indonesia } \\ \text { Field of study } & : & \text { Wayang Studies,Javanese Culture }\end{array}$

Name $\quad$ : $\quad$ Dr. Bambang Sunarto, M. Sn

Occupation : : Lecturer, Institut Seni Indonesia, Surakarta

Field of study : : Art Studies 